\title{
Environmental Intelligence Concept in Indigenous Knowledge
}

\author{
Zukya Rona Islami*, Ramdan Afrian, Faiz 'Urfan \\ Department of Geography Education \\ Universitas Samudra \\ Langsa, Aceh, Indonesia \\ *zukya.rona.islami@unsam.ac.id
}

\begin{abstract}
The higher the level of community intelligence, the better the management and conservation of the environment in the community. the concept of environmental intelligence is expected to already exist. This is evidenced by the success of our ancestors in maintaining the environment. But the progress of the times made the concept of nature eroded. therefore, this research seeks to raise the concept of environmental intelligence based on indigenous knowledge to be applied and sustainable. Through a literature study, this article aims to describe the concept of environmental intelligence in peace of indigenous knowledge. Environmental intelligence and indigenous knowledge relationships are very strong suggestions, prohibitions, and sanctions in the indigenous knowledge. Indigenous knowledge that existed in society who believed and made a habit can be formed skills in preserving the environment and can establish expertise in addressing environmental problems that exist. And it is the primary indicator of a person is said to have an intelligent environment. author's suggestion for subsequent research is that this concept can be better developed so that it can be formulated into an environmental intelligence indicator.
\end{abstract}

Keywords-indigenous knowledge, environmental intelligence

\section{INTRODUCTION}

This Knowledge is a term used to represent the values and norms that are believed, understood, and implemented local community based on their knowledge and experience for interacting with the environment [1,2]. Local knowledge is formed of behaviour, habits, traditions, and local knowledge that has been entrenched in the community. local knowledge is an attitude, outlook, and the ability of a community to manage its environment to survive in that environment [3]. Local knowledge can also be said to be my response to a geographical-geopolitical situation, histories and situational locally [1].

Humans and the environment are the two elements that cannot be apart, all human activity affects the environment. Human activity environmentally friendly will produce a good quality environment, but human activities that are not environmentally friendly will produce poor environmental quality [4]. The fact that we experienced today is environmental problems such as pollution and damage to continuing and expanding [5]. This proves that the activities and behaviours of today's society no longer oriented toward environmental sustainability. One form of environmental damage the image below.

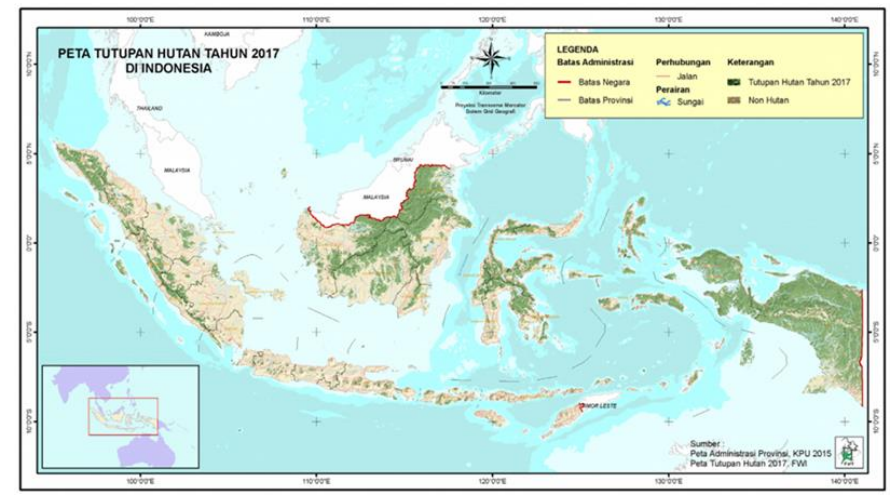

Fig. 1. Map of Forest Cover 2017 in Indonesia.

The picture (Figure 1) shows forest cover in Indonesia. Based on the picture, it appears that Indonesia is experiencing a land cover crisis, there is no green anymore that indicates forest cover. The picture shows the regions of Sumatra, Java, NTT and NTB, Kalimantan and Sulawesi. Therefore, it can be said that almost all regions of Indonesia experience a crisis of forest cover. This is only one example is still a lot of damage and other pollution that is befalling our environment.

Various environmental problems today require a conscious and intelligent community in treating the environment. community in managing the environment is reflected in the use of natural resources beyond the capacity to grow and the low quality of human resources involved in the management of natural resources and the environment [6]. Humans have a responsibility towards nature and other living beings, by promoting the principles of morally regulate how humans manage or use of natural resources and the environment [3].

Addressing environmental problems requires a search intricacy of human spiritual, philosophy of life, awareness of nature and behaviour while maintaining the balance of nature 
[7]. It required the intelligence of the human environment, such as understanding the human relationship with all the elements as well as other creatures that exist in the surrounding environment [8]. The concept of environmental bits of intelligence will give you an idea that the man who has the intelligence environment will position itself as a controller on the environment. Intelligence environment will make human beings care about the environment, and they can criticize the current environmental conditions caused by human activity.

Previous research conducted by Neto concerning the effect of gender and culture on intelligence, the results of the study showed that culture will affect one's intelligence [9]. In addition, the study of Stepanicev and his friends stated that to protect the environment requires environmental intelligence, which means the ability to protect the environment. This study uses sophisticated networks as alarms for environmental intelligence. Some of this research shows the link between culture and intelligence, and the need for environmental intelligence to protect the environment itself [10].

The concept of environmental intelligence expected already exists and has been passed down from generation to generation. This is evidenced by the success of our ancestors keep their surroundings before the role of government and NGOs, as now $[1,11]$. However, inheritance is non-formal and if don't maintain then it will be affected by globalization. Therefore, in this article, the author wants to examine the concept of environmental intelligence that exists in indigenous communities.

\section{METHODS}

This research is a literature study. This study aims to find the concept of environmental intelligence based on related references. The research began by finding and collecting references in the form of articles from reputable national and international journals. Articles are obtained by reading articles. about intelligence, local culture, the environment and the relationship between culture and intelligence of a person. Theories and references obtained are used as a foundation and main tool for research practice. The type of data used by the authors in this study is secondary data is data obtained from journals, book documentation, and the internet [10].

Data that has been obtained from various relevant references are then analysed by descriptive analysis methods. The descriptive analysis method in this research is done by describing the facts which are then followed by analysis, not only describing, but also providing sufficient understanding and explanation.

\section{RESULTS AND DISCUSSION}

Results and discussion will examine how intelligence is an environment, how Indigenous knowledge can shape the environment and the intelligence of what challenges and obstacles in preserving indigenous communities.

\section{A. What is Intelligence?}

Intelligence is the ability of a person includes knowledge, skills, and expertise to address the problem. Intelligence involves the five senses to obtain information, which is then received by the brain to become knowledge [12,13], Knowledge and thought processes coupled with experience will produce intelligence in individuals [14]

Howard Gardner states that everyone has intelligence [13]. Intelligence is not just about being able to answer test questions, more than that intelligence means capable problems in tangible form and diverse situations [15]. Therefore, everyone has intelligence, but in a different form [13]. The Intelligence of a human describes a person's mental ability to produce /obtain /receive/ integrate the knowledge they have. An intelligent person determines the ability to make decisions and /or determine its ability to act effectively [16] smart people, means the person is unable to make decisions or be able to act effectively to quickly and accurately when faced with a problem [17]. An intelligent person capable of giving arguments, able to solve problems, to think abstractly, able to learn and understand new material, and were able to take advantage of the knowledge /experience of its [14]

Based on the explanation above, it can be said that intelligence is not only due to the more hereditary factor, but the innate intelligence will also be heavily influenced by the environment. The surrounding environment of different individuals will provide different knowledge and experience for everyone so that the intelligence held will depend on several elements, namely: the senses, knowledge, and skills Therefore, Gardner's opinions on all humans have wit was correct.

\section{B. Environmental Intelligence in Indigenous Knowledge}

We already know what intelligence is, how the nature of intelligence and everyone has intelligence, including environmental intelligence. Based on the above exposure, it can be said that environmental intelligence is the ability to know environmental issues (acquired from five senses), skills in nurturing the environment (derived from the belief in local culture) and the ability to solve environmental problems (derived from experience and habits in local communities) (Fig. 2). A detailed explanation will be discussed in the next paragraph.

The environment is everything outside the individual or organism and the effect on their lives. For example, human life is influenced by weather conditions, soil water, animals, plants, culture. political, economic and others. All of it affects people's lives so that all of it is also referred to as environmental [7]. Geography studies define the environment not only of geographical conditions in the form of the physical environment and human environment, but other factors are the dimension of Spatial. Therefore, it can be said that the environment is all land, both physical landscaping and cultural landscapes including human element or its inhabitants (human resources), plus the accessibility of concerned areas [18]. 
Based on the foregoing, in this paper, the authors focus on culture as part of the environment. The culture itself consists of attitudes, values, beliefs, and behaviours shared by a group of people who communicate from one generation to the next through language or other communication means. One element of culture is indigenous knowledge. Indigenous knowledge consists of two forms, namely, pragmatic knowledge of the world's natural/ongoing goals, and indigenous knowledge of the culture and the subjective world. Pragmatic knowledge of the objective world can be observed in a way of knowledge explanations and descriptive knowledge. While the indigenous knowledge of local communities can be observed by observing the basic forms of rules, norms, values produced by culture, religion, and morals. The rules, norms, and values are passed on from generation to generation as habits that the locals must apply. The application of knowledge is reflected in people's behaviour. This public behaviour was born of local knowledge and beliefs that existed in society. Indigenous knowledge and community confidence will endure behaviours and skills in preserving the environment

Several studies describing the indigenous knowledge and connection in the preservation of the environment, namely: Syarif et al' research [19] which explain the culture [Install Ri Kajang which is a philosophy of life of indigenous peoples Ammatoa in the forest preserve, Pawarti et al [20] which explains the deep local knowledge ban to protect the environment in the Minangkabau people, Sumarmi research [21] knowledge society keep perch in the woods. Besides the forest, experiment of Sumarmi [22] Osing community describes local wisdom in preserving water resources. Do's and don'ts in the local knowledge that is the basis of the formation of environmental intelligence. people who behave in accordance with the do's and don'ts in the local wisdom would know the environment, skilled keep their environment and capable of resolving the existing environmental problems, because in addition do's and don'ts, local knowledge also know the sanctions for people who do not abide by the custom.

Based on the discussion that has been presented above, researchers formulated a scheme of the interrelationship between the formation of environmental intelligence in indigenous knowledge. The scheme can be seen in fig 2 below:

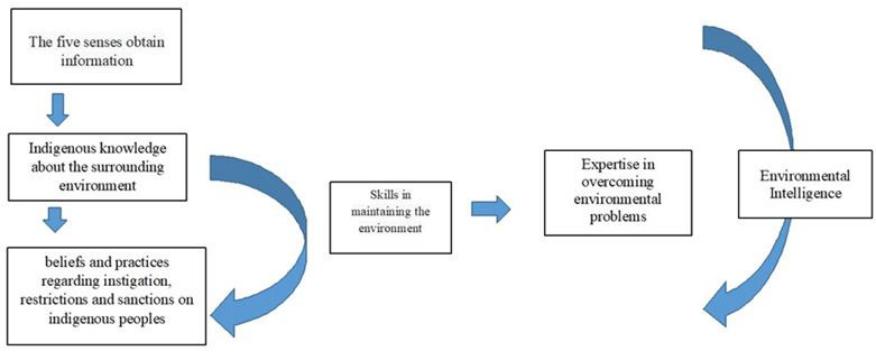

Fig. 2. Environment intelligence in indigenous knowledge.

\section{CONCLUSION}

Environmental intelligence and indigenous knowledge relationships are very strong suggestions, prohibitions, and sanctions in the indigenous knowledge. Indigenous knowledge that existed in society who believed and made a habit can be formed skills in preserving the environment and can establish expertise in addressing environmental problems that exist. And it is the primary indicator of a person is said to have an intelligent environment. The Author's suggestion for subsequent research is that this concept can be better developed so that it can be formulated into an environmental intelligence indicator.

\section{ACKNOWLEDGMENT}

The authors thank LPPM and PM, Samudra University. We would also like to thank colleagues for supporting and providing helpful advice and corrections to this research.

\section{REFERENCES}

[1] H.A. Wibowo, W. Wasino and D.L. Setyowati, "Kearifan Lokal dalam Menjaga Lingkungan Hidup (Studi Kasus Masyarakay di Desa Colo Kecamatan Dawe Kabupaten Kudus),” J. Educ. Sos. Stud., vol. 1, no. 1, pp. 25-30, 2012.

[2] R. Mungmachon, "Knowledge and Local Wisdom: Community," Int. J. Humanit. Soc. Sci., vol. 13, pp. 174-181, 2012

[3] A. Retnowati, E. Anantasari, M.A. Marfai and A. Dittmann, "Environmental Ethics in Local Knowledge Responding to Climate Change: An Understanding of Seasonal Traditional Calendar PranotoMongso and its Phenology in Karst Area of GunungKidul, Yogyakarta, Indonesia," Procedia Environ. Sci., vol. 20, pp. 785-794, 2014

[4] I. Indrawardana, "Kearifan Lokal Adat Sunda dalam Hubungan dengan Lingkungan Alam,” Komunitas, vol. 4, no. 1, pp. 1-8, 2012.

[5] M.S. Sinapoy, "Kearifan Lokal Masyarakat Adat Suku Moronene dalam Perlindungan dan Pengelolaan Lingkungan Hidup," HOLREV, vol. 2, no. 2, pp. 513-542, 2018

[6] S. Gallhofer, K. Gibson, J. Haslam, P. McNicholas, and B. Takiari, "Developing environmental accounting: insights from indigenous cultures," Account. Audit. Account. J., vol. 13, no. 3, pp. 381-409, 2000 .

[7] J. Widodo, "Urban Environment and Human Behaviour: Learning from History and Local Wisdom,” Procedia - Soc. Behav. Sci., vol. 42, pp. 6 11,2012 .

[8] R. Utina, "Kecerdasan Ekologis Dalam Kearifan Lokal Masyarakat Bajo Desa Torosiaje Provinsi Gorontalo," Prosiding Konferensi Dan Seminar Nasional Pusat Studi Lingkungan Hidup Indonesia, vol. 21, no. 5, pp 14-20, 2012.

[9] F. Neto, A. Furnham and R. Paz, "Sex and culture differences in perceptions of estimated multiple intelligence for self and family: A Macanese-Portuguese comparison," Int. J. Psychol., vol. 42, no. 2, pp. 124-133, 2007.

[10] D. Stipanicev, Lj. Bodrozic, and M. Stula, "Environmental Intelligence Based on Advanced Sensor Networks," in 2007 14th Internationa Workshop on Systems, Signals and Image Processing and 6th EURASIP Conference focused on Speech and Image Processing, Multimedia Communications and Services, Maribor, Slovenia, pp. 209-212, 2007.

[11] A. Agatha, "Traditional Wisdom in Land Use and Resource Management Among the Lugbara of Uganda: A Historical Perspective," SAGE Open, vol. 6, no. 3, p. 215824401666456 , Sep. 2016. 
[12] H.J. Eysenck, "The concept of 'intelligence': Useful or useless?," Intelligence, vol. 12, no. 1, pp. 1-16, 1988.

[13] E. Barrington, "Teaching to student diversity in higher education: how Multiple Intelligence Theory can help," Teach. High. Educ., vol. 9, no. 4, pp. 421-434, 2004.

[14] A. Demetriou, "Intelligence in Cultural, Social and Educational Context," in International Encyclopedia of the Social \& Behavioral Sciences, Elsevier, pp. 313-322, 2015.

[15] S. Ramsden, F.M. Richardson, G. Josse, M.S. Thomas, C. Ellis, C. Shakeshaft and C.J. Price, "Verbal and non-verbal intelligence changes in the teenage brain," Nature, vol. 479, no. (7371), pp. 113-116, 2011.

[16] D. Bratko, A. Butkovic, T. Vukasovic, T. Chamorro-Premuzic, and S. von Stumm, "Cognitive ability, self-assessed intelligence and personality: Common genetic but independent environmental aetiologies," Intelligence, vol. 40, no. 2, pp. 91-99, 2012.

[17] I.J. Deary, "Intelligence," Annu. Rev. Psychol., vol. 63, no. 1, pp. $453-$ $482,2012$.
[18] H. Hastuti and A. Suhardjo, "Keterkaitan Lingkungan Geografi, Kondisi Sosialekonomi Dan Pembagian Kerja Secara Seksual Diperdesaan," Maj. Geogr. Indones., vol. 20, no. 2, pp. 94-113, 2006.

[19] E. Syarif, A. Fatchan and K. Astina, "Tradition of" Pasang Ri-Kajang" in the forests managing in system mores of "Ammatoa" at District Bulukumba South Sulawesi, Indonesia," Mediterranean Journal of Social Sciences, vol. 7, no. (6), pp. 325-325, 2016.

[20] A. Pawarti, H. Purnaweni, and D. D. Anggoro, "Nilai Pelestarian Lingkungan dalam Kearifan Lokal Lubuk Larangan Ngalau Agung di Kampuang Surau Kabupaten Dharmasraya Provinsi Sumatera Barat," pp. 98-103, 2012.

[21] S. Sumarmi, "The Local Genius of Tengger People in Conserving Forest and Increasing Economic Benefits Using Agroforestry System," IOP Conf. Ser. Earth Environ. Sci., vol. 145, p. 012135, 2018.

[22] S. Sumarmi, "Local Wisdom of Osing People in Conserving Water Resources,” Komunitas Int. J. Indones. Soc. Cult., vol. 7, no. 1, p. 43, 2015 